Wojciech J. Katner

Uniwersytet Łódzki

\title{
SŁUSZNOŚĆ JAKO KLAUZULA GENERALNA W KODEKSIE CYWILNYM (Z PERSPEKTYWY ORZECZNICTWA SĄDU NAJWYŻSZEGO)
}

1. Klauzule generalne niezmiennie odgrywają istotną rolę w praktyce prawniczej i stale zaprzątają uwagę doktryny. Dzieje się tak, mimo ogólnie bardzo znacznego wzrostu przepisów we wszystkich dziedzinach prawa i coraz szczegółowszego normowania stosunków społecznych oraz gospodarczych. Nie jest jednak możliwe przewidzenie wszystkich sytuacji wymagających interwencji organów stosujących prawo i wtedy okazuje się, że klauzule generalne są niezbędne w celu podjęcia sprawiedliwych decyzji.

Liczne są także określenia pojęcia klauzul generalnych, jednak sprowadzają się one do dość zgodnego rozumienia ich istoty. Chodzi więc o wyrażenia o charakterze ogólnym, odpowiadające zasadom prawa stanowionego i jego stosowania, umożliwiające elastyczność oraz dostosowanie prawa do konkretnych sytuacji społecznych i gospodarczych. To ogólne stwierdzenie odnoszące się do wszystkich klauzul generalnych, jakimi się posługuje porządek prawny, ma zastosowanie również do klauzuli najczęściej podnoszonej przez podmioty prawa i wykorzystywanej w orzecznictwie, jaką jest słuszność, nazwana w warunkach politycznych powstawania kodeksu cywilnego z 1964 r. i przepisów go poprzedzających - zasadami współżycia społecznego. Od razu na początku wskażę, że opowiadam się za tymi głosami, które utożsamiają ze sobą te pojęcia, podobnie jak inne podobne, pełniące tę samą funkcję w prawie cywilnym. Tak więc na gruncie kodeksu zobowiązań z 1933 r. były to zasady słuszności, dobrych obyczajów, dobrej wiary, względy moralne i porządek publiczny, w kodeksie handlowym z 1934 r. - dobre obyczaje kupieckie, w przepisach ogólnych prawa cywilnego z 1946 r. - dobra wiara, a w przepisach ogólnych prawa cywilnego z 1950 r. - już zasady współżycia społecznego.

Kontekst polityczny, w jakim określenie zasad współżycia społecznego zostało użyte, a następnie rozmaite pomysły co do rozumienia i znaczenia tych zasad, których ich autorzy dzisiaj zapewne by nie użyli, doprowadziły do swoistego ich zdeprecjonowania, przypisania im nieraz ustrojowego (socjalistycznego, a nawet 
komunistycznego) pochodzenia i zwłaszcza w młodszym pokoleniu przedstawicieli doktryny, do zakwestionowania racji ich umieszczenia w kodeksie, a nawet do prób ich odrzucenia. Jest to ocena niesłuszna, najczęściej świadcząca o dość płytkim zbadaniu problemu i zbyt łatwym wyrażeniu negatywnego przekonania tylko poprzez kontekst historyczny oraz przykłady zastosowania, niezasługującego na aprobatę. Przypomnieć należy, że spore grono teoretyków prawa, w tym zajmujących się prawem cywilnym z powodzeniem thumaczyło w ówczesnym czasie istotę zasad współżycia społecznego; było to racjonalne i pozbawione zabarwień ideologicznych, a w kolejnych opracowaniach tematu dość powszechnie przyjmowane. Szczególne znaczenie miało uniwersalne określenie, zaproponowane przez Prof. Z. Ziembińskiego w 1972 r., według którego, najkrócej mówiąc, chodzi o reguły moralnego postępowania podmiotów prawa, akceptowane w danym społeczeństwie w określonym czasie, niebędące normami stanowionymi przez przepisy prawa. Takim rozumieniem zasad współżycia społecznego, bez własnego roztrząsania samego pojęcia posługiwało się i nadal posługuje wielu cywilistów, co widać poprzez przyjmowane przez nich założenia lub wprost odniesienia do takiego wythumaczenia ,zasad”, całkiem powszechne w latach siedemdziesiątych i nowszych. ${ }^{1} \mathrm{~W}$ moim przekonaniu, uzasadnia to zamienne posługiwanie się de lege lata pojęciem zasad współżycia społecznego i zasad słuszności lub w odpowiednim kontekście sytuacyjnym - również zasadami dobrej wiary i dobrych obyczajów. W kodeksie rodzinnym i opiekuńczym rolę odpowiadającą temu pełnią zasady dobra rodziny i dobra dziecka, w prawie rzeczowym i zobowiązaniowym uzupełnienie stanowi nieraz (nie zawsze) społeczno-gospodarcze przeznaczenie prawa i społeczno-gospodarcze przeznaczenie rzeczy. W niektórych przypadkach klauzule te występują obok siebie, jakby chcąc sobą ogarnąć całą konkretną sytuację faktyczną i prawną, żeby sprawiedliwie ocenić rozpoznawaną - np. przez sąd - sprawę. Spoglądając na ogół spraw, w których przywoływane są zasady współżycia społecznego lub ich różne odpowiedniki albo pojęcia podobne, najchętniej omawiany termin sprowadziłbym do krótkiego stwierdzenia: człowieku, zachowuj się przyzwoicie, a co to znaczy, doskonale wie każda średnio nawet przygotowana do życia osoba, samodzielnie decydująca o swoim postępowaniu.

W swym pierwszorzędnym podręczniku o części ogólnej prawa cywilnego Profesor Aleksander Wolter dokonał wkrótce po wejściu w życie kodeksu cywilnego usystematyzowania przepisów, w których występują zasady współżycia społecznego, według roli, jaką pełnią w stosunkach cywilnoprawnych. ${ }^{2}$ Ujął je w trzech grupach: pierwsza to przepisy odnoszące się do skutków naruszenia zasad współ-

\footnotetext{
1 Ten trafny, moim zdaniem, punkt widzenia wielokrotnie w swych licznych opracowaniach podkreślał Prof. A. Szpunar; sam problem jest omawiany szeroko przez A. Stelmachowskiego, Wstęp do teorii prawa cywilnego, Warszawa 1969 oraz Zarys teorii prawa cywilnego, Warszawa 1998.

2 A. Wolter, Prawo cywilne. Zarys części ogólnej, Warszawa 1967; A. Wolter, J. Ignatowicz, K. Stefaniuk, Prawo cywilne. Zarys części ogólnej, Warszawa 2001.
} 
życia społecznego przez podmiot prawa, poprzez dezaprobatę powodującą nieważność lub bezskuteczność czynności prawnej. Chodzi o art. 5, art. $58 \S 2$, art. 704, art. 93 , art. $353^{1}$, art. 754 i art. 1008 pkt 1 k.c., przy czym znaczenie tych przepisów jest różne, a najczęściej powoływane jest nadużycie prawa (art. 5 k.c.), nieważność czynności prawnej, zwłaszcza umowy (art. 58 § 2 k.c.) oraz nieważność (nieskuteczność) oświadczeń stron kreujących sprzecznie z zasadami współżycia społecznego umowę nienazwaną (art. $353^{1}$ k.c.). Drugą grupę tworzą przepisy, w których powstanie, zmiana lub ustanie stosunku cywilnoprawnego zależy od oceny zachowania podmiotu z punktu widzenia respektowania zasad współżycia społecznego. Są to: art. $357^{1}$, art. $358^{1} \S 3$, art. 411 pkt 2, art. 428 , art. $431 \S 2$, art. 440 , art. 446 $\S 2$, art. $826 \S 2$, art. 827 i art. 902 k.c. Na szczególną uwagę zasługują tu te przepisy o charakterze ogólnym, które wywierają istotny wpływ na stosunki gospodarcze, jak dotyczący zastosowania klauzuli rebus sic stantibus w art. $357^{1}$ k.c. oraz możliwości waloryzacji sądowej świadczenia pieniężnego $\mathrm{w}$ art. $358^{1} \S 3$ k.c., a także wyłączenia zwrotu nienależnego świadczenia (bezpodstawnego wzbogacenia) w art. $411 \mathrm{pkt}$ 2 k.c. i odszkodowania na rzecz pośrednio poszkodowanego wskutek śmierci osoby bliskiej w art. $446 \S 2$ k.c. Trzecią grupę tworzą przepisy, w których zasady współżycia społecznego stanowią kryterium określenia treści stosunku cywilnoprawnego. Odnosi się to do art. 56, art. $65 \S 1$, art. 140, art. 233, art. 287, art. 298 i art. 354 k.c. To najbardziej ogólne i różnorodne przepisy, w których umieszczenie wspomnianej klauzuli generalnej jest nieraz bardzo przydatne dla dookreślenia treści danego prawa lub oceny zamiarów składającego oświadczenie woli. W praktyce orzeczniczej nadzwyczaj często powoływane są w sporach z odwołaniem się do konieczności respektowania zasad współżycia społecznego art. 56 i art. $65 \S 1$ k.c. (kwestie skutków i wykładni oświadczeń woli), art. 140 i odpowiadający mu art. 233 k.c. (granice prawa własności i prawa użytkowania wieczystego), jak też istotny w stosunkach gospodarczych między przedsiębiorcami art. 354 k.c. (współdziałanie dłużnika i wierzyciela w wykonaniu zobowiązania).

Dokonany podział nie ma tylko charakteru doktrynalnego. Porządkuje on wydatnie spojrzenie na różną rolę zasad współżycia społecznego, czyli zasad słusznego postępowania w obrocie w różnych stanach prawnych. Wprawdzie zasady te rozumie się dla nich wszystkich tak samo, ale ich zastosowanie jest już różne, zależne od przypisanej im roli. Ich wspólna ocena pozwala jednak na wyróżnienie subiektywnego i obiektywnego punktu widzenia, czego wybór jest potrzebny do osiągnięcia poczucia sprawiedliwego rozstrzygnięcia konkretnej rozpoznawanej sprawy. Może się wydawać, że w stosunkach między osobami fizycznymi w tzw. obrocie powszechnym winno się uwzględnić poczucie słuszności tej osoby, od której oczekujemy pożądanego zachowania lub dla praw której to słuszne zachowanie innego podmiotu ma mieć znaczenie. $\mathrm{Z}$ kolei, w obrocie gospodarczym, zwłaszcza sensu stricto, a więc między przedsiębiorcami powinno dominować obiektywne spojrze- 
nie z pozycji obrotu jako pewnej całości, odzwierciedlającej poziom gospodarczy i przeciętne zachowania przedsiębiorców na rynku.

Wydaje się, że byłoby to dość powierzchowne traktowanie problemu. Współczesny obrót prawny w swej całości skłania się do obiektywizacji zachowań, gdyż tylko wtedy są one mierzalne i możliwe do porównania z przyjmowanym ogólnie, w jakimś stopniu znanym lub wyobrażalnym szablonem powinnego (oczekiwanego) zachowania. Nawet więc w kwestiach moralnych należy dążyć do pewnych wzorców, unikając skrajności, zwłaszcza mających podłoże ideologiczne. Współczesne stosunki społeczne co chwilę pokazują na konsekwencje nadmiernej ideologizacji zachowania ludzi, skutkiem czego jest sprawianie krzywdy tym, którzy zachowują się inaczej, co nie znaczy, że źle i moralnie zasługujących na dezaprobatę. Dokonując oceny obiektywnej, według ogólnej koncepcji Prof. Ziembińskiego, o czym na początku była mowa, uzna się za słuszne zachowanie, które zmieści się w granicach wytyczonego szablonu. Przypomnieć wypada, że cała tzw. teoria wewnętrzna nadużycia prawa, którą przyjmuje art. 5 k.c. opiera się na obiektywizacji ocen postępowania słusznego, odpowiadającego zasadom współżycia społecznego. ${ }^{3} \mathrm{Nie}$ powinno mieć znaczenia, czy chodzi o stosunki prawne w obrocie gospodarczym i niegospodarczym. Dla jednego i drugiego winno się tworzyć, w konkretnych stosunkach prawnych zawieranych umów i innych czynności, modele zachowania uczciwego, jak to nazwałem ogólnie - przyzwoitego, obowiązującego strony (podmioty) tych stosunków, od których przestrzegania zależy ocena pozytywna lub negatywna z punktu widzenia zasady słuszności (zasad współżycia społecznego).

$\mathrm{Na}$ koniec pierwszej części tego opracowania należy zwrócić uwagę na aspekt konstytucyjny zasad współżycia społecznego. Konstytucja RP nie posługuje się tym pojęciem, natomiast w art. 2 odwołuje się w zamanifestowaniu, że Polska jest demokratycznym państwem prawnym do zasad sprawiedliwości społecznej. W społecznym charakterze sprawiedliwości można się dopatrzeć słuszności, przyzwoitości, lojalności i dobrej wiary w postępowaniu oczekiwanym od obywateli w ich stosunkach wzajemnych.

Zajmując się wątpliwościami zgłoszonymi wobec obowiązywania najczęściej stosowanego w praktyce przepisu odwołującego się do zasad współżycia społecznego, to znaczy art. 5 k.c. - Trybunał Konstytucyjny w wyroku z dnia 17 października 2000 r. ${ }^{4}$ w sprawie SK 5/99 uznał ten przepis za zgodny z Konstytucją. Trudno mi wyobrazić sobie inne rozstrzygnięcie, raczej można się zastanawiać nad racjonalnością argumentów kwestionujących konstytucyjność art. 5 k.c., jako niezwykle ważnej normy chroniącej przed nadużywaniem prawa. Trybunał skorzystał z okazji

3 A. Szpunar, Nadużycie prawa podmiotowego, Kraków 1947; M. Pyziak-Szafnicka, Prawo podmiotowe, (w:) System Prawa Prywatnego, t. 1, Prawo cywilne - część ogólna, red. M. Safjan, Warszawa 2012, s. 876 i n.; Z. Radwański, A. Olejniczak, Prawo cywilne - część ogólna, Warszawa 2013, s. 104-108; wcześniej J. Justyński, Nadużycie prawa w polskim prawie cywilnym, Kraków 2000. 
i przypomniał, że przepis ten nie kształtuje jakichś własnych praw podmiotowych ani ich nie zmienia, dotyczy każdego podmiotu prawa i może być stosowany wyjątkowo, w razie spełnienia trzech warunków prawnych poprawności jego użycia, tzn. zachowania przesłanek obiektywnych, jednolitości stosowania w celu uzyskania przewidywalności ocen oraz nienadawania przez sądy nowej treści art. 5 k.c. ${ }^{5}$

2. Pora na bliższe zajęcie się orzecznictwem Sądu Najwyższego dotyczącym wspomnianego kilkakrotnie art. 5 k.c., jako przepisu odwołującego się do zasad współżycia społecznego wtedy, gdy podmiot podejmuje obronę przed kierowanymi do niego roszczeniami ze względu na ich sprzeczność z zachowaniem ocenianym jako słuszne (uczciwe, przyzwoite, moralne), a nie są skuteczne inne środki przewidziane prawem. Materia zostanie podzielona na kilkanaście rodzajów spraw, w których powołanie się na konstrukcję art. 5 k.c. i sprzeczność zachowania z zasadami współżycia społecznego była w okresie ostatnich kilku lat najczęstsza. Celem prezentacji spraw nie jest ocena trafności rozstrzygnięć, lecz uzmysłowienie, jak nadal potrzebny w praktyce jest wspomniany przepis i jak ważną rolę w stosunkach cywilnoprawnych pełni niezmiennie klauzula generalna zasad współżycia społecznego.

Projekty zastąpienia jej w nowym kodeksie cywilnym, przygotowywanym pracowicie przez Komisję Kodyfikacyjną Prawa Cywilnego przy Ministrze Sprawiedliwości - zasadą słuszności, jak starałem się dotąd wykazać, nie zmieni istoty tej klauzuli generalnej, jej treści i zastosowania w przyszłości. Zmianie mogą ulec akcenty kładzione dla rozumienia, czym jest słuszność w postępowaniu podmiotu prawa cywilnego, ale nie sądzę, aby mogło to wpłynąć na aktualność orzecznictwa mającego kilkudziesięcioletnią tradycję i wyraźną jednolitość pojmowania słuszności (zasad współżycia społecznego).

Najpierw kwestia ogólniejsza, to znaczy odpowiedzenie na wątpliwości, czy dla powołania się na niezgodność z zasadami współżycia społecznego musi się wskazać konkretnie naruszoną zasadę, czy można to uczynić w sposób uogólniający. Przeważa opinia, że naruszona zasada powinna zostać nazwana i wskazana przez podmiot powołujący się na jej naruszenie. Takie stanowisko jest utrwalone w orzecznictwie, na dowód czego można powołać wyrok Sądu Najwyższego z dnia 3 lutego 1998 r., ${ }^{6}$ w którym zostało stwierdzone, że na treść zasad współżycia składają się akceptowane i godne ochrony reguły rzetelnego postępowania w stosunkach społecznych. Wymagają więc one konkretyzacji w każdej sprawie, w której wchodzi w grę zarzut nadużycia prawa podmiotowego; należy zatem ustalić i przytoczyć w uzasadnieniu wyroku te okoliczności, które pozostają w sprzeczności z regułami moralnymi wymagającymi przestrzegania i „dopiero wówczas możliwa jest subsumpcja ustalonego stanu pod normę wynikającą z art. 5 k.c.". Podobny punkt widzenia został

$5 \quad$ Zob. na temat wyroku Trybunału M. Pyziak-Szafnicka, Prawo.., op. cit., s. 882-884.

$6 \quad$ I CKN 459/97, Legalis nr 92593. 
zaprezentowany w wyrokach Sądu Najwyższego: z dnia 14 października 1998 r. ${ }^{7}$ i z dnia 31 maja 2006 r. $^{8}$

Jakby podsumowaniem orzecznictwa $\mathrm{w}$ omawianym względzie jest wyrok Sądu Najwyższego z dnia 11 kwietnia 2013 r., ${ }^{9}$ w którym chodziło o dość prozaiczną sprawę wniesienia przez powodów wkładu do spółdzielni rolniczej w postaci gruntów rolnych, a następnie po wystąpieniu ze spółdzielni niemożności wyegzekwowania od niej albo zwrotu tego wkładu, albo nieruchomości zamiennej, albo ekwiwalentu pieniężnego, nawet po uzyskaniu korzystnego dla powodów prawomocnego wyroku sądowego. Jego niewykonanie było uzasadniane sprzecznością z ogólnie przedstawianymi zasadami współżycia społecznego. Jak trafnie stwierdził Sąd Najwyższy w motywach, które warto przytoczyć, ,w doktrynie wypracowane zostało rozumienie zasad współżycia społecznego jako norm moralnych odnoszących się do stosunków międzyludzkich, które stanowią klauzule generalne, mające znaczenie dla całego systemu prawa cywilnego; wyróżniają się one od innych zwrotów niedookreślonych tym, że odsyłają do norm moralnych. Są one wyróżniane przez pewne wartości powszechnie uznawane w społeczeństwie, a ich przestrzeganie spotyka się z pozytywną oceną, zaś naruszanie z dezaprobatą. Mają na celu aksjologiczną relatywizację prawa. Przepis art. 5 kc. ustanawia zakaz korzystania w określonych granicach z praw podmiotowych, wytyczony kryteriami sprzeczności ze społeczno-gospodarczym przeznaczeniem prawa lub zasadami współżycia społecznego, które uzasadniają uznanie określonego działania lub zaniechania za nadużycie prawa."

W kolejności, Sąd Najwyższy odwołał się do kilku wcześniejszych swoich orzeczeń, w których wskazał na art. 5 k.c. jako przepis mający na celu zapobieganie stosowania prawa w sposób, który prowadzi do skutków niemoralnych albo rozmijających się zasadniczo z założeniem jego uchwalenia. Przepis ten ma wyją̧tkowy charakter, a odmowa udzielenia ochrony na jego podstawie „musi być uzasadniona okolicznościami rażącymi i nieakceptowanymi ze względu na system wartości istniejący w społeczeństwie (...) Objęte art. 5 k.c. zasady współżycia społecznego pozostają w nierozłącznym związku z całokształtem okoliczności konkretnej sprawy (...) i wyznaczają podstawy, granice oraz kierunek jej rozstrzygnięcia, w wyjątkowych sytuacjach, które ten przepis przewiduje (...) Odwoływanie się ogólnikowo do zasad współżycia społecznego, a zatem odwoływanie się ogólnikowo do klauzul generalnych przewidzianych w art. 5 k.c. nie może podważać pośrednio mocy obowiązujących przepisów; należy zatem wskazać, jaka z przyjętych w społeczeństwie zasad została naruszona". ${ }^{10}$

II CKN 928/97, OSNC 1999, nr 4, poz. 75.

IV CSK 149/05, Legalis $\mathrm{nr} 179598$.

II CSK 438/12, Lex nr 1341662

10 W tym wyroku jest odwołanie się do wyroków SN: z dnia 22 listopada 1994 r., II CRN 127/94, niepubl.; z dnia 4 kwietnia 1997 r., II CKN 118/97, niepubl.; z dnia 4 października 1998 r., II CKN 928/97, OSNC 1999, nr 4, poz. 75; z dnia 3 października 2000 r., I CKN 308/00, niepubl.; z dnia 4 października 2001 r., I CKN 428/00, niepubl., 
W wyroku z dnia 23 maja 2013 r. ${ }^{11}$ Sąd Najwyższy stanowczo stwierdził, że w art. 5 k.c. następuje w istocie odesłanie do zasad słuszności, dobrej wiary w znaczeniu obiektywnym i zasad uczciwości, obowiązujących w stosunkach cywilnoprawnych.

Jako pierwsze zostaną omówione sprawy dotyczące zarzutu nadużycia prawa ze względu na zasady współżycia społecznego w wypadku powoływania się dłużnika na przedawnienie roszczeń. Problem zaostrzył się po nowelizacji kodeksu cywilnego w 1990 r. i uchyleniu art. 117 § 3 k.c., pozwalającego na nieuwzględnienie przedawnienia roszczeń $\mathrm{w}$ razie sprzeciwienia się temu poprzez ocenę uwzględniającą zasady współżycia społecznego, z zachowaniem w stanie faktycznym przesłanek ustawowych, wskazanych przez powołany przepis. Brak normy szczególnej uruchomił odwoływanie się do art. 5 k.c., którego zastosowanie było wcześniej wyłączane ze względu na wskazany przepis. ${ }^{12}$

W wyroku z dnia 16 czerwca 2009 r. ${ }^{13}$ Sąd Najwyższy powtórzył dawniej wypowiedziany pogląd, ${ }^{14}$ że w stosunkach między przedsiębiorcami jedynie wyjątkowo można uznać podniesienie zarzutu przedawnienia za nadużycie prawa. W sprawie chodziło o oddalenie powództwa o zapłatę przewoźnego wraz z opłatami spedycyjnymi, co zostało przez stronę powodową, będącą elektrownią uiszczone, ale nie przekazane wierzycielowi - spółce z o.o. W uzasadnieniu wyroku wskazano na błędną wykładnię art. 5 k.c., gdyż dla skutecznego podniesienia zarzutu nadużycia prawa nie było konieczne wskazanie lub zdefiniowanie konkretnej zasady współżycia społecznego naruszonej przez zarzut przedawnienia. Wystarczające było przytoczenie okoliczności uzasadniających ten zarzut, na co wskazywałby całokształt tych okoliczności, a pod kątem ich wystąpienia sprawa nie została rozpoznana, przez co nie można było stwierdzić, że przesłanki do zastosowania art. 5 k.c. nie zostały wykazane; to dało wystarczającą podstawę do uchylenia wyroku sądu drugiej instancji, zaskarżonego skargą kasacyjną.

W sprawie zakończonej wyrokiem Sądu Najwyższego z dnia 10 kwietnia 2013 r. ${ }^{15}$ chodziło o stwierdzone przedawnienie roszczeń skierowanych przez powódkę przeciwko jednemu z dwóch pozwanych szpitali o odszkodowanie, zadośćuczynienie i rentę wskutek zarzucenia im popełnienia błędów w leczeniu. Badając skargę kasacyjną z punktu widzenia zarzutu nadużycia prawa przez odwołanie się do przedawnienia roszczeń, Sąd Najwyższy stwierdził, wskazując na liczne orzecznictwo SN, że w wyjątkowych wypadkach można za pomocą klauzuli zawartej w art. 5

z dnia 7 maja 2003 r., IV CKN 120/01, niepubl.; z dnia 31 maja 2006 r., IV CSK 149/05, niepubl.; z dnia 9 grudnia 2009 r., IV CSK 290/09, niepubl. i z dnia 6 kwietnia 2011 r., II PK 254/10, niepubl.

11 IV CSK 660/12, Lex nr 1365725.

12 Zob. też M. Sekuła-Leleno, Podniesienie zarzutu przedawnienia a nadużycie prawa podmiotowego w rozumieniu art. 5 k.c. na tle orzecznictwa Sądu Najwyższego, „lus Novum” 2011, nr 1.

I CSK 522/08, Legalis nr 265756.

Wyrok Sądu Najwyższego z dnia 27 czerwca 2001 r., II CKN 604/00, OSNC 2002, nr 3, poz. 32.

IV CSK 611/12, Lex nr 1365718. 
k.c. rozwiązywać kolizję wartości przejawiającej się w pewności stosunków prawnych, chronionej instytucją przedawnienia oraz wartości, jaką stanowi prawo pokrzywdzonego do uzyskania ochrony prawnej naruszonego dobra. „Sąd może zatem nie uwzględnić upływu przedawnienia dochodzonego roszczenia, jeżeli podniesienie przez dłużnika zarzutu przedawnienia nastąpiło w okolicznościach objętych hipotezą art. 5 k.c." ${ }^{16}$ Jednakże trzeba uwzględnić szczególny charakter tego przepisu i oceniając, czy zarzut przedawnienia stanowi nadużycie prawa uznać za rozstrzygające okoliczności konkretnego wypadku, zachodzące po stronie poszkodowanego i podmiotu zobowiązanego do naprawienia szkody, zwłaszcza odnośnie do charakteru uszczerbku, jaki doznał poszkodowany, przyczyna opóźnienia w dochodzeniu roszczenia i czas jego trwania. „Możliwość zastosowania art. 5 k.c. nie zawsze jednak musi być wiązana z negatywną oceną zachowania osoby zobowiązanej do naprawienia szkody, przejawiającego się w utrudnianiu wcześniejszego dochodzenia roszczenia przez poszkodowanego". ${ }^{17} \mathrm{~W}$ rozpoznawanej sprawie ustalono poważne schorzenia powódki, będącej w młodym wieku, wielokrotne jej hospitalizowanie, poddawanie różnym zabiegom oraz terapii antydepresyjnej. Jednocześnie sądy $\mathrm{w}$ toku instancji nie stwierdziły, aby między nieprawidłowościami w postępowaniu lekarzy jednego z pozwanych szpitali a stanem zdrowia powódki nie zachodził adekwatny związek przyczynowy, tak więc uchylenie wyroku ze względu na zastosowanie klauzuli generalnej z art. 5 k.c. jedynie umożliwiało w stosunku do tego pozwanego ponowne rozpoznanie sprawy.

$\mathrm{Na}$ koniec tego fragmentu rozważań warto wskazać na wyrok Sądu Najwyższego z dnia 27 listopada 2013 r., ${ }^{18}$ w którym znalazło się stwierdzenie, że ,zastosowanie art. 5 k.c. w odniesieniu do zarzutu przedawnienia zakłada rozważenie, na tle całokształtu okoliczności sprawy, interesów i postaw obu stron roszczenia, tj. zarówno uprawnionego, jak i zobowiązanego. Nie jest przy tym wykluczone uznanie zarzutu przedawnienia za nadużycie prawa także wtedy, gdy przyczyny opóźnienia w dochodzeniu roszczenia leżą również, a nawet wyłącznie po stronie uprawnionego. $\mathrm{W}$ takim wypadku za uznaniem zarzutu przedawnienia za nadużycie prawa mogą przemawiać inne okoliczności sprawy, np. charakter uszczerbku leżącego u podstaw przedawnionego roszczenia lub szczególna sytuacja uprawnionego, zwłaszcza w zestawieniu z sytuacją zobowiązanego, czy wreszcie sama postawa zobowiązanego." W sprawie o odszkodowanie za skutki śmierci osoby bliskiej w 2002 r., potrąconej przez samochód, który najechał na dzika na autostradzie, powódki wniosły pozew dopiero w 2008 r., a więc po upływie trzyletniego okresu przedawnienia.

\footnotetext{
16 Powołane zostały m.in.: uchwała SN z dnia 10 marca 1993 r., III CZP 8/93, OSNC 1993, nr 9, poz. 153 oraz późniejsze orzeczenia, w tym wyrok SN z dnia 13 listopada 1997 r., I CKN 323/97, OSNC 1998, nr 5, poz. 79, z dnia 27 czerwca 2001 r., II CKN 604/00, OSNC 2002, nr 3, poz. 32 oraz uchwała Pełnego Składu Izby Cywilnej Sądu Najwyższego z dnia 17 lutego 2006 r., III CZP 84/05, OSNC 2006, nr 7-8, poz. 114.

17 Odwołano się do uzasadnienia uchwały Pełnego Składu Izby Cywilnej Sądu Najwyższego z dnia 17 lutego 2006 r., III CZP 84/05.

18 V CSK 516/12, Lex nr 1422124.
} 
Drugim rodzajem spraw, w których poszukuje się ochrony w art. 5 k.c. są próby przerwania biegu zasiedzenia własności nieruchomości przez wniesienie pozwu o zwrot tej nieruchomości ostatniego dnia przed upływem terminu zasiedzenia.

Odnosząc się tylko do spraw z ostatniego okresu należy zwrócić uwagę na postanowienie z dnia 18 grudnia 2013 r., ${ }^{19}$ w którym Sąd Najwyższy stwierdził, że sprzeczne z poczuciem słuszności jest złożenie przez Skarb Państwa ostatniego dnia biegu terminu zasiedzenia nieruchomości wniosku o charakterze windykacyjnym, skutkującego przerwą biegu zasiedzenia, w okolicznościach oczywistego zaniedbania przez kilkadziesiąt lat własnych interesów wynikających z prawa własności. W konkretnej sprawie zostało ustalone, że w 1960 r. małżonkowie nabyli notarialnie udział wynoszący $1 / 2$ własności działki, przy czym okazało się później, iż jej część znajdowała się na cudzej działce, którą w 1974 r. uzyskał Skarb Państwa jako spadek bezdziedziczny. Nie interesował się nią w ogóle aż do czasu rozpoznawania tej sprawy, nie wydając nawet decyzji komunalizacyjnej po 1990 r. Nieruchomość była $\mathrm{w}$ posiadaniu samoistnym wspomnianych małżonków, opłacali oni podatki i byli uważani przez sąsiadów za jej właścicieli, oni też zainicjowali postępowanie zmierzające do uregulowania stanu prawnego, gdy okazało się, że stan faktyczny nie odpowiada stanowi prawnemu, wreszcie wystąpili o zasiedzenie. Wtedy dopiero gruntem zainteresował się Skarb Państwa i gmina, występując o zniesienie współwłasności i w ten sposób zamierzając odzyskać nieruchomość.

We wskazanym postanowieniu zostały wypowiedziane istotne słowa. Po pierwsze, nie zostało zanegowane i uznane za sprzeczne $\mathrm{z}$ art. 5 k.c. samo wniesienie przez właściciela ostatniego dnia biegu zasiedzenia wniosku o charakterze windykacyjnym. Nadużycie prawa przez Skarb Państwa dotyczyło okoliczności, w jakich wniosek ten został złożony i wymagało zastanowienia, czy ze względów słusznościowych można akceptować zachowanie, w którym cel ma uświęcać zastosowane środki. Celem było niedopuszczenie do utraty własności (współwłasności) nieruchomości przez Skarb Państwa, więc sam ten cel nie mógł być uznany za sprzeczny z zasadami współżycia społecznego. Dokonanie jakiejś czynności prawnej lub procesowej ostatniego dnia terminu oznacza jego zachowanie i samo przez się nie stanowi nadużycia prawa. Po drugie, zgodnie $\mathrm{z}$ teorią wewnętrzną nadużycia prawa, znajdującą odbicie w art. 5 k.c. wykonywanie prawa w sposób sprzeczny z zasadami współżycia społecznego nie jest uważane za wykonywanie tego prawa i nie korzysta z ochrony. Jeżeli więc Skarb Państwa przez kilkadziesiąt lat nie interesował się swoją własnością, nawet wtedy, gdy wspomniani małżonkowie wbrew własnym interesom faktycznym i prawnym zainicjowali postępowanie na rzecz tegoż Skarbu Państwa o uregulowanie sytuacji prawnej powstałej wskutek nabycia spadku bezdziedzicznego pół wieku wcześniej, to złożenie wniosku mającego odzyskać nieruchomość od jej posiadaczy w ostatnim dniu jej zasiedzenia przez nich musi być 
uznane za sprzeczne z poczuciem słuszności, czyli z wyrażonymi wprost przez art. 5 k.c. zasadami współżycia społecznego.

Na tle wskazanej sprawy pojawia się szersza refleksja, związana ze sprawami o zasiedzenie nieruchomości objętych w posiadanie od 1945 r. w wyniku działań wojennych i regulacji prawnych z ówczesnego czasu (jak zwłaszcza tzw. dekret warszawski, ustawa nacjonalizacyjna i zakres wykonania dekretu o reformie rolnej).

Nie sposób w ramach tych uwag bliżej zająć się tymi kwestiami, ponieważ całe opracowanie należałoby temu poświęcić. Jest wielce nie w porządku ze strony władz ustawodawczych i wykonawczych Rzeczpospolitej, że od czasu transformacji ustrojowej po 1989 r. nie został uregulowany prawnie problem reprywatyzacji i w ręce sądów złożone zostały sprawy roszczeń, nieraz wielce wątpliwych i wnoszonych w warunkach zasiedzenia oraz ciągłego ocierania się o nadużycie prawa i zastosowanie art. 5 k.c., w sytuacji, gdy niesprawidliwości dziejowych nie da się sprawiedliwie osądzić z zastosowaniem przepisów nie do takich sytuacji stworzonych. Zagadnienie tylko ze względów porządkowych jest tu podniesione, ponieważ łączy się bezpośrednio z tytułową problematyką. ${ }^{20}$

Trzecim rodzajem spraw, na które warto zwrócić uwagę w orzecznictwie Sądu Najwyższego ostatnich lat z punktu widzenia art. 5 k.c., jest domaganie się przez Agencję Restrukturyzacji i Modernizacji Rolnictwa (dalej jako Agencja) zwrotu dofinansowania do kredytów przyznanych rolnikom, na których nałożony był obowiązek uzupełnienia wykształcenia w określonym terminie. Wśród wydanych orzeczeń wyróżniają się zwłaszcza wyroki Sądu Najwyższego z dnia 21 marca 2013 r., z dnia 24 kwietnia 2013 r. i z dnia 12 czerwca 2013 r. ${ }^{21}$ Ustalone w tych sprawach stany faktyczne są dosyć podobne, tzn. młodzi rolnicy otrzymywali pomoc inwestycyjną, częściowo ze środków Unii Europejskiej, zobowiązując się zdobyć w zakreślonym terminie wykształcenie rolnicze, co z różnych przyczyn w tym czasie się nie udawało i mimo uzyskania tego wykształcenia, ale później, wymagano od nich zwrotu środków finansowych prawidłowo zainwestowanych w gospodarstwo rolne.

Najbardziej jaskrawym przykładem wątpliwego uzasadnienia żądania zwrotu był stan faktyczny w sprawie II CSK 642/12. Pozwany był inżynierem telekomunikacji po studiach politechnicznych, a ponadto uzyskał tytuł magistra w zakresie zarządzania przedsiębiorstwem. Po dwóch latach pracy w zawodzie zdecydował się objąć gospodarstwo rolne rodziców. Chcąc uzyskać dofinansowanie zobowiązał się wobec wspomnianej Agencji, że uzyska wykształcenie rolnicze na zapropono-

20 Na marginesie tych uwag podnieść należy, że nietrafnie w ostatnim czasie podważa się zawetowanie ustawy re-
prywatyzacyjnej przez Prezydenta A. Kwaśniewskiego, gdyż ustawa ta nie była dobrze skonstruowana i przewi-
dywała ze szkodą dla interesów Skarbu Państwa zbyt hojne odszkodowania oraz warunki prawne do zwracania
nieruchomości byłym właścicielom lub ich następcom prawnym, nie wyłączając także zbywalności wierzytelno-
ści z tego tytułu. Prawidłowo ukształtowany projekt ustawy reprywatyzacyjnej został przedłożony rządowi J. Ka-
czyńskiego przez poprzedni rząd, ale prace ustawodawcze nad tym projektem nie zostały podjęte w ówczesnym
Sejmie. Są to sprawy II CSK 241/12, niepubl., IV CSK 621/12, Lex nr 1353258 oraz II CSK 642/12, Lex nr 1363016. 
wanych mu czteromiesięcznych kursach eksternistycznych (sic!), które miał odbyć w latach 2008-2009, jednak w 2008 r. kursy te zlikwidowano. Rozpoczął więc w 2009 r. naukę w technikum rolniczym w formie indywidualnego toku nauczania i w czerwcu 2010 r. uzyskał tytuł technika-rolnika. Jednak już w lutym 2010 roku Agencja poinformowała pozwanego, że w grudniu 2009 r. upłynął termin do złożenia dokumentów poświadczających uzyskanie kwalifikacji zawodowych, a skoro to nie nastąpiło, to zgodnie $\mathrm{z}$ podjętym zobowiązaniem pozwany powinien zwrócić kwotę ponad 80 tysięcy złotych dofinansowania wraz z odsetkami w wysokości jak za zaległości podatkowe. Sąd pierwszej instancji uznał, że żądanie Agencji jest w okolicznościach sprawy sprzeczne z zasadami współżycia społecznego, jednak sąd drugiej instancji z powołaniem się na szereg przepisów Unii Europejskiej oraz prawa krajowego, wymagających uzupełnienia wykształcenia rolniczego najdłużej w ciągu pięciu lat od rozpoczęcia działalności rolniczej, a ze względu na to, że pozwany ten okres przekroczył, zmienił wyrok i obciążył rolnika wymienioną kwotą. Nie dopatrzył się jednocześnie w żądaniu zwrotu pomocy finansowej przez Agencję naruszenia art. 5 k.c.

Całkiem odmiennie ocenił ustalony stan faktyczny Sąd Najwyższy. W przytoczonym na wstępie wyroku z dnia 12 czerwca 2013 r. podkreślił wprawdzie, że art. 5 k.c. powinien być stosowany powściągliwie z uwagi na pochodzenie środków pomocowych i zasad nimi dysponowania, to jednak podmioty prawa publicznego, od których wymaga się troski o ochronę interesów państwa powinny dbać o to, by kierując się interesem powszechnym nie krzywdzić nikogo swoim postępowaniem. ${ }^{22}$ Odwołując się do wskazanego wyroku z dnia 24 kwietnia 2013 r. Sąd Najwyższy uznał za właściwe, w ramach konstrukcji nadużycia prawa podmiotowego, położenie akcentu na celu przepisów oraz społecznej i gospodarczej treści stosunku prawnego łączącego strony. Słusznie więc stwierdził, że celem pomocy udzielonej pozwanemu było doprowadzenie do zmodernizowania gospodarstwa rolnego i zwiększenia jego rentowności, co w rzeczywistości nastąpiło, zgodnie z rozporządzeniem Rady WE nr 12157/1999 w sprawie wsparcia obszarów wiejskich z Europejskiego Funduszu Orientacji i Gwarancji Rolnej (EFOGR). Jest chyba oczywiste, że nie można do tego przyłożyć takiej samej miary, jak do nie mającego bezpośredniego znaczenia dla wykorzystania środków pomocowych kilkumiesięcznego opóźnienia w zdobyciu dodatkowego wykształcenia przez pozwanego mającego wcześniej ukończone dwa fakultety. Z jednej więc strony na aprobatę zasługuje troska Agencji o to, aby środki publiczne były prawidłowo wykorzystane, zgodnie z zawartymi umowami, z drugiej jednak nie można akceptować formalistycznego podejścia Agencji, sprzecznego z istotą tych umów i z obowiązkiem współdziałania wierzyciela z dłużnikiem przy ich wykonaniu (art. 354 § 2 k.c.). Dlatego postępowanie Agencji zostało oce- 
nione jako sprzeczne z art. 5 k.c. i orzeczenie sądu drugiej instancji zostało zasadnie uchylone.

Kolejna grupa spraw dotyczy umów zawieranych z bankiem. W wyrokach Sądu Najwyższego z dnia 10 stycznia 2013 r. oraz z dnia 23 maja 2013 r. ${ }^{23}$ chodziło o wypowiedzenie przez bank umowy kredytu bankowego ze względu na niespłacanie przez dłużników w terminie rat kredytowych. W obu sprawach przyczyny zaległości miały usprawiedliwienie zasługujące na ich przyjęcie, w każdym razie umowy nie powinny były być wypowiadane „w trybie dyscyplinarnym”.

W sprawie IV CSK 679/12 bank wypowiedział umowę kredytu bankowego i zażądał zasądzenia od trojga pozwanych solidarnie kwoty ponad ćwierć miliona franków szwajcarskich (CHF) wraz z odsetkami umownymi w wysokości czterokrotności stopy kredytu lombardowego (20\%), w sytuacji zawarcia umowy kredytowej na 35 lat i zalegania wobec banku raty spłaty kredytu wraz z odsetkami zaledwie za półtora miesiąca, wynoszącej niecałe dwa tysiące CHF. Wprawdzie zadłużenie to uprawniało formalnie bank nawet do wypowiedzenia umowy, ale słusznie zostało przyjęte, że w okolicznościach sprawy bank nadużył swojego prawa podmiotowego. W szczególności nie podjął nawet działań sprawdzających, czy pojawienie się stwierdzonej niewielkiej zaległości zagraża spłacie kredytu, nie zastosował też przewidzianego umową trybu postępowania w razie powstania przeterminowanego zadłużenia, co chroniło wystarczająco interesy banku jako instytucji kredytującej na wypadek przejściowych trudności w spłacie kredytu.

W orzecznictwie podkreśla się, że banki mają uprzywilejowaną pozycję wobec kredytobiorców, m.in. mogąc jednostronnie kształtować łączący strony stosunek prawny, w tym również zmieniając warunki umów oraz mogąc je wypowiedzieć z różnych przyczyn. To sprawia, że korzystanie z szerokich uprawnień przez banki musi być poddane ocenie sądu, także odnośnie do skorzystania z prawa podmiotowego kształtującego, wynikającego z przepisu lub z treści umowy, a dokonać tego można przez pryzmat art. 5 k.c. Dlatego badając skuteczność wypowiedzenia umowy kredytowej, co stanowi uprawnienie najbardziej dotkliwe dla biorącego kredyt, należy rozważyć skalę i stopień naruszenia przez niego obowiązków, uwzględniając wysokość udzielonego kredytu, czas, na jaki został udzielony, dotychczasową realizację warunków umowy i przyczyny niepłacenia $\mathrm{w}$ terminie należnych rat. $\mathrm{Za}$ zasadne należy uznać rozstrzygnięcie korzystne dla klientów banku, w uzasadnieniu którego uznano podjęte przez bank działanie we wskazanych okolicznościach sprawy za niewspółmierne do uchybień pozwanego przy wykonywaniu umowy, a uwzględniając ponadto nieprzeprowadzenie przez bank żadnych działań sprawdzających jego zachowanie musiało zostać ocenione jako naruszające dobre obyczaje, czyli według art. 5 k.c. zasady współżycia społecznego. 
Do potrzeby odniesienia się do zachowania przez strony umowy z bankiem zasad współżycia społecznego odwołał się Sąd Najwyższy w powołanym już wyroku z dnia 10 stycznia 2013 r., w którym dodatkowo zwrócono uwagę na to, że wykorzystanie wynikających z umowy kredytowej lub z przepisów prawa uprawnień banku do jednostronnej modyfikacji umowy kredytowej i wypowiedzenia części lub całości kredytu nie może być uznane za nadużycie prawa, jeżeli zostało powzięte po stwierdzeniu, iż niespełnienie przez kredytobiorcę warunków ustalonych w umowie co do spłaty kredytu i oprocentowania jest następstwem utraty zdolności kredytowej przez dłużnika lub pogorszenia jego sytuacji materialnej w stopniu zagrażającym zdolności do spłaty przez niego tego zadłużenia. ${ }^{24}$

Mając na uwadze instytucje finansowe warto wskazać na wyrok Sądu Najwyższego z dnia 19 września 2013 r., ${ }^{25}$ w stanie faktycznym którego chodziło o zawarcie przez spółkę jawną umowy ramowej z bankiem, a jej przedmiotem było uregulowanie zasad zawierania i rozliczania transakcji walutowych, terminowych i pochodnych, w tym opcji walutowych. Istotą późniejszych sporów na tle tej umowy, przygotowanej w projekcie przez bank, przewidującej nierówne szanse stron (zwłaszcza nieekwiwalentność świadczeń, obciążenie klienta banku nadmiernym ryzykiem zmian kursu walut, zminimalizowanie tego ryzyka dla banku, który przewidział tylko dla siebie barierę kursową), było zawarcie wielu transakcji opcji walutowych, których końcowym wynikiem było poniesienie dotkliwych strat finansowych przez spółkę.

Rozpoznając sprawę z punktu widzenia ważności zawartej umowy ze względu na naruszenie art. 58 k.c., a nie art. 5 k.c. ${ }^{26}$ Sąd Najwyższy stwierdził, że z zasad współżycia społecznego, określanych w takich sprawach także mianem lojalności i uczciwości w obrocie gospodarczym wynika, że umowa wzajemna powinna po obu stronach stwarzać równorzędne warunki jej realizacji. Wprawdzie powodowa spółka znała warunki prawne zawieranych umów oraz zawarła wiele podobnych transakcji wcześniej, ale to nie sprawia, że umowy te można uznać za uczciwe. $Z$ analiz ekonomicznych, ogłaszanych publicznie w związku z umowami opcji pojawiły się wątpliwości co do ich zgodności z zasadami słuszności, to znaczy uczciwego obrotu gospodarczego, nie związanego ze spekulacjami na rynku finansowym i z natury rzeczy narażonego na zarzut naruszenia zasad współżycia społecznego. Dlatego obiektywnie niekorzystna dla jednej strony treść umowy zasługuje na negatywną ocenę moralną, co w konsekwencji doprowadziło do uznania umowy za sprzeczną z zasadami współżycia społecznego w sytuacji, gdy do takiego ukształtowania stosunków umownych, który jest dla niej w sposób widoczny krzywdzący doszło wsku-

24 Tak też wcześniej Sąd Najwyższy w wyroku z dnia 13 lutego 2004 r., IV CK 40/03, Lex nr 151636.

25 ICSK 651/12, Biul. SN 2013, nr 11, poz. 17; OSNC 2014, nr 7-8, poz. 76.

26 Powoływane orzeczenie Sądu Najwyższego odbiega od zastosowania art. 5 k.c., jako klauzuli nadużycia prawa, a zgodność zachowania strony umowy jest oceniana ze względu na zasady współżycia społecznego, jako kryterium ważności czynności prawnej (art. 58 § 2 k.c.). 
tek świadomego lub tylko spowodowanego niedbalstwem wykorzystania silniejszej pozycji przez drugą stronę umowy.

3. W końcowej części tego opracowania warto wskazać na jeszcze kilka sytuacji, w których Sąd Najwyższy odwołał się w ostatnich latach do zasad współżycia społecznego (zasad słuszności), jednak pominięte zostaną bardziej szczegółowe omówienia spraw, a uwaga zostanie zwrócona jedynie na rodzaj tych spraw i znaczenie zastosowania przy ich rozstrzyganiu art. 5 k.c.

Najpierw uwagę zwraca wyrok Sądu Najwyższego z dnia 14 listopada 2013 r., ${ }^{27}$ $\mathrm{w}$ którym ponowiona została utrwalona $\mathrm{w}$ orzecznictwie i doktrynie teza co do tego, że art. 5 k.c. nie może stanowić samodzielnej podstawy powództwa. Stanowisko to ma dodatkowe uzasadnienie wtedy, gdy nie ma potrzeby sięgania do tego przepisu wskutek możliwej i pozwalającej na rozstrzygnięcie sporu wykładni innych przepisów, regulujących bezpodstawne wzbogacenie, hipotekę i postępowanie egzekucyjne.

W drugiej kolejności prezentowanych orzeczeń wypada odwołać się również do utrwalonego poglądu, związanego ze stosowaniem art. 5 k.c. i konstrukcji nadużycia prawa, jakim jest bezskuteczność powoływania się na zasady współżycia społecznego $\mathrm{w}$ celu ochrony własnych interesów przez podmiot sam nie przestrzegający tych zasad. Wyrok Sądu Najwyższego z dnia 9 grudnia 2009 r. ${ }^{28}$ dotyczy sprawy o ochronę dóbr osobistych znanej firmy handlowej, której przedsiębiorca - dostawca zarzucił w programie telewizyjnym popełnienie wobec niego kradzieży. Odwołując się jedynie do podniesionej w sprawie kwestii zasad współżycia społecznego, których zastosowania wobec siebie domagał się powód, Sąd Najwyższy odmawiając mu tego stwierdził, że już samo wystąpienie przez powoda z powództwem o ochronę dóbr osobistych było sprzeczne z zasadami współżycia społecznego i stanowiło nadużycie prawa. Wnosząc je powód nie tyle dążył do uzyskania ochrony swoich dóbr osobistych, co do powstrzymania pozwanych w ich niewygodnej dla powoda działalności związanej z jego słuszną krytyką i nagłaśnianiem negatywnych aspektów jego działalności.

Powództwo pozostawało w związku z wcześniejszym zachowaniem powoda w stosunku do pracowników i dostawców, wobec których stale i w sposób drastyczny naruszał zasady współżycia społecznego. Powód wykorzystując swoją dominację stosował nieuczciwe, sprzeczne z prawem i zasadami współżycia społecznego praktyki utrudniające lub wręcz uniemożliwiające uzyskanie przez pozwanego należnej zapłaty za dostarczone towary, co stanowiło element ogólnej strategii powoda oszukiwania dostawców. W tej sytuacji nadmiernie emocjonalna wypowiedź pozwanego znajdowała usprawiedliwienie we wzburzeniu i poczuciu krzywdy wywołanym 
postępowaniem powoda, a zatem udzielenie powodowi ochrony prawnej byłoby sprzeczne z zasadami współżycia społecznego.

Podobną, co do istoty, sprawą była ta rozstrzygnięta wyrokiem Sądu Najwyższego z dnia 12 czerwca 2013 r. ${ }^{29}$ Podstawą oddalenia powództwa spółki z o.o. przeciwko osobie fizycznej był art. 5 k.c. ze względu na uznanie nielojalności powoda względem pozwanej dlatego, że powódka była jednocześnie komandytariuszem pozwanej spółki, a jej prokurent, którym był prezes zarządu powodowej spółki odmówił współdziałania z pozwaną w procesie wytoczonym przeciwko tej spółce; skutkowało to niemożnością podjęcia jakiejkolwiek obrony przez spółkę komandytową i tym samym godziło w jej interesy oraz interesy pozwanej, odpowiadającej jako komplementariusz, subsydiarnie wraz ze spółką.

Gdyby na tym poprzestać, to zrozumiałe było uznanie przez sądy w toku instancji, że zachowanie powódki było nielojalne wobec partnera handlowego i niezgodne $\mathrm{z}$ dobrymi obyczajami kupieckimi. Jednakże trafne okazało się podniesienie w skardze kasacyjnej powódki, że nielojalność należy zarzucić nie jej, lecz pozwanej, która nie zapłaciła powodowi za dostarczone wino, zwodziła ją przez długi czas obietnicami dokonania zapłaty przez pozwaną spółkę i jej komplementariusza - pozwaną w tej sprawie, prowadzącą sprawy spółki i ją reprezentującą. Nie można więc uważać powoda za sprzeniewierzającego się zasadom współżycia społecznego tylko dlatego, że domagał się wykonania obowiązków wynikających ze stosunków prawnych łączących powodową spółkę z pozwaną. $Z$ istoty swojej domaganie się należnego świadczenia przez wierzyciela z tytułu wykonania ważnie zawartej umowy nie może być uważane za sprzeczne z zasadami współżycia społecznego (art. 5 k.c.) tylko dlatego, że wierzyciel - spółka z o.o. jest komandytariuszem w spółce komandytowej, będącej dłużnikiem i domaga się od niego zapłaty ceny za rzeczy sprzedane w wyniku umowy handlowej, pozostającej poza stosunkiem spółki łączącym strony tej umowy.

W dwóch wyrokach z dnia 24 stycznia 2013 r. ${ }^{30}$ Sąd Najwyższy zajął się kwestią słuszności żądania zwrotu bonifikaty udzielonej przy wykupie lokalu mieszkalnego, w sytuacji zbycia tego lokalu z zyskiem przed upływem terminu wymaganej karencji. Wyroki te odwołały się do wcześniejszych judykatów ${ }^{31}$ dotyczących tego samego problemu, w których właściciele lokali, którzy nie dochowali warunków nabycia mieszkań z bonifikatą pozostają w niezgodzie z zasadami współżycia społecznego, nie mogą więc skutecznie zwalczać prawa do dochodzenia zwrotu udzielonej im bonifikaty zarzucając naruszenie art. 5 k.c.

29 II CSK 632/12, Lex nr 1353432.

30 Dwa wyroki Sądu Najwyższego z dnia 24 stycznia 2013 r. w sprawach: II CSK 271/12, Lex nr 1293948 oraz II CSK 286/12, Lex nr 1293949.

31 Chodzi w szczególności o wyrok Sądu Najwyższego z dnia 25 sierpnia 2011 r., II CSK 640/10, Lex nr 964496. 
W kręgu spraw mieszkaniowych znajduje się wyrok Sądu Najwyższego z dnia 26 lutego 2013 r. ${ }^{32} \mathrm{~W}$ rozpoznawanej sprawie chodziło o sprzedaż w drodze licytacji lokalu mieszkalnego, za który przez szereg lat właściciel odmawiał ponoszenia opłat na rzecz wspólnoty mieszkaniowej. W uzasadnieniu zostało podkreślone, że wszelkie rozstrzygnięcia dotyczące ograniczenia lub unicestwienia praw podmiotowych wymagają ostrożności i wnikliwego rozważenia wszystkich aspektów konkretnego wypadku. Odmowa udzielenia ochrony może być uzasadniona okolicznościami wyjątkowymi, rażącymi i nieakceptowanymi ze względów aksjologicznych, ewentualnie teleologicznych; w rozpoznawanej sprawie okoliczności takie nie wystąpiły, skoro pozwany uporczywie uchylał się od obowiązku ponoszenia należnych opłat, a więc odmowa udzielenia ochrony powodowej wspólnocie mieszkaniowej utwierdziłaby pozwanego w przekonaniu o prawidłowości jego postępowania, a to z punktu widzenia art. 5 k.c. jest nie do zaakceptowania.

Na koniec przedstawić należy uchwałę siedmiu sędziów Sądu Najwyższego z dnia 20 czerwca 2013 r., ${ }^{33}$ w której uznane zostało, że art. 5 k.c. nie ma zastosowania do upływu terminu przewidzianego w art. $568 \S 1$ k.c. Ważkie i do obrony są zarówno argumenty uzasadniające podjętą uchwałę, wypływające głównie z zawitego charakteru terminu zawartego $\mathrm{w}$ tym przepisie, jak i stanowisko przeciwstawne, uznające za zasadne stosowanie art. 5 k.c. we wszystkich stosunkach cywilnoprawnych, wyrażone poprzez zdanie odrębne Sędziego SN, Profesora Krzysztofa Pietrzykowskiego. ${ }^{34}$ 


\section{EQUITY AS A GENERAL CLAUSE IN THE CIVIL CODE (FROM THE PERSPECTIVE OF THE SUPREME COURT)}

The paper presents the important role played by the general clauses in the practice of law and the doctrine. The author presents the concept of a general clause, analyzes examples of general clauses in the Polish law, the legal literature, and in historical perspective. He draws attention to the constitutional aspect of the principle of equity, and goes on to discuss the importance of equity by analyzing the decisions of the Constitutional Court and the Supreme Court.

Keywords: The principle of equity, general clauses, the Supreme Court 